\title{
Nectar foraging by stingless bees in Costa Rica: botanical and climatological influences on sugar concentration of nectar collected by Melipona
}

\author{
Jacobus C. Biesmeijer*, Martin J.A.P. Smeets, Julliette A.P. Richter, \\ Marinus J. Sommeijer
}

Ethology and Socio-ecology Group, Laboratory of Comparative Physiology, Utrecht University, PO Box 80.086, 3508 TB Utrecht, the Netherlands

(Received 2 March 1998; accepted 23 October 1998)

\begin{abstract}
Nectar foraging by two species of stingless bees, Melipona beecheii and Melipona fasciata, was studied in Costa Rica. In the humid forest environment $M$. beecheii collected more concentrated nectar than $M$. fasciata. Pollen analysis showed that their nectar sources overlapped considerably and that $M$. beecheii collected richer nectar than $M$. fasciata even from the same plant species. Thus, the botanic origin of the nectar explained only part of the differences. There was no difference in the sugar concentration of the nectar collected by the two species at a dry tropical site where $M$. fasciata was introduced and $M$. beecheii occurs naturally. In the dry habitat, both species collected more concentrated nectar than at the humid site. Foraging behaviour of the bees is suggested as the basis for resource partitioning in humid forests. Inra/DIB/AGIB/Elsevier, Paris
\end{abstract}

Melipona / nectar foraging / sugar concentration / pollen analysis / Costa Rica

\section{INTRODUCTION}

The nectar foraging community in tropical habitats is very diverse $[2,13]$ and plants and animals have evolved many adaptations concerning nectar production and collect- ing [6], e.g. variation in nectar quality and quantity in plants $[2,3]$ and morphology of nectar uptake organs of nectar collectors [17]. Flower visitors partition nectar resources based on the amount of nectar in a flower [13], the sugar concentration [13,

\footnotetext{
* Correspondence and reprints: Apartado Postal 2270, 3000 Heredia, Costa Rica

E-mail: kbiesmei@sol.racsa.co.cr
} 
$19,22]$, the type of sugar [2], the amino acid composition [22] and the lipid composition of the nectar [2].

In the Neotropical lowlands the most abundant group of nectar collecting insects are the stingless bees, subfamily Meliponini $[8,9]$. Because stingless bees are eusocial and live in large permanent colonies, they collect pollen and nectar all the year round and are polylectic [17]. Several dozen species of Meliponini occur sympatrically and their diets partly overlap in terms of plant species used $[11,12,15,16,21,22$, 24]. Roubik and Buchmann [19] observed that, in Panama, two species of Melipona, $M$. compressipes and $M$. marginata, used and might prefer higher sugar concentrations than the other two species, $M$. fasciata and M. fuliginosa. Another species, $M$. beecheii, was found to be a high-sugar specialist in Quintana Roo, Mexico [22]. These studies did neither identify the floristic origin of the nectar nor related the results to climatological variation, but attributed the differences in sugar concentration to a variation in imbibing rates and to the caloric rewards that the different species obtained from different sugar solutions [19].

Factors that influence the sugar content of the nectar that bees harvest, especially botanical origin and local climate, have mainly been studied separately (see above cited papers). Therefore, our main aim was to relate data on bee-collected nectar to botanical origin of the nectar and variation in regional climate. These data were used to investigate whether partitioning of nectar resources is based on preferences of the bees for certain plant species or regional climate. We selected two congeneric sympatric stingless bees, Melipona beecheii and M. fasciata, and analysed the sugar concentration of the nectar they collected and related it to the time of day, the seasonal variation, the regional climate and botanical origin of the nectar.

The two species are sympatric only in a small zone in Costa Rica (transition between dry forest and rain forest) and allopatric in the remaining part of their distribution (figure 1). M. beecheii is a Central American

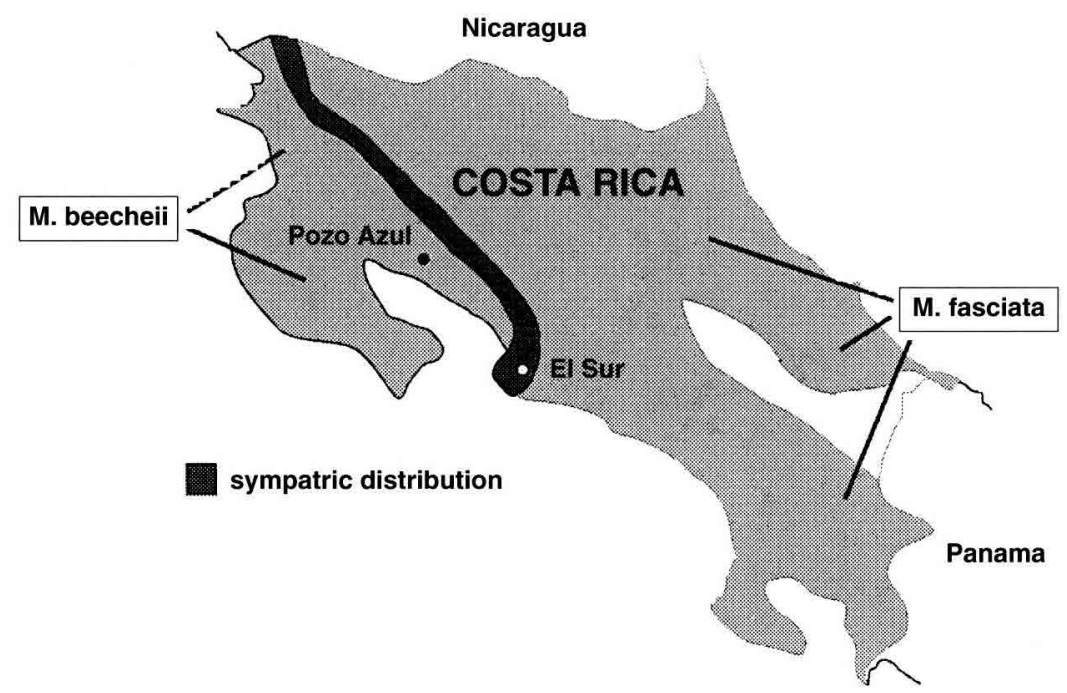

Figure 1. Distribution of $M$. beecheii and M. fasciata in Costa Rica. Indicated is the location of the two study sites: Pozo Azul and El Sur de Turrubares. The map is based on the collections present in Costa Rica (INBIO, UCR, CINAT), a database of Jorge Lobo (UCR), unpublished data and literature references $[5,25]$. 
species and is found from Mexico (Yucatan Peninsula and Quintana Roo) to Costa Rica, mainly in the dry forest zones ([1]; Biesmeijer, unpublished data). $M$. fasciata is a member of a species complex that is widely distributed in Central and South America $[7,18,23]$, mainly in the humid lowlands. Our bees probably belong to the same species as $M$. panamica in Roubik et al. [22]. We will refer to it as $M$. fasciata following Hanson and Gauld [7].

Studying these two species allowed us to assess: 1) whether they show similar highand low-sugar specialisation as reported in allopatry $[19,22] ; 2)$ the variation and botanical origin of the nectar; and 3) the influence of regional climate on the sugar content of the collected nectar.

\section{MATERIALS AND METHODS}

\subsection{Study sites and bee colonies}

Most observations were carried out in El Sur de Turrubares, San José Province, Costa Rica $\left(9^{\circ} 45^{\prime} \mathrm{N} ; 4^{\circ} 35^{\prime} \mathrm{W}\right.$; alt. $180 \mathrm{~m}$; figure I). El Sur was chosen because it is situated in a zone where the distribution of the two bee species overlaps.

Nine colonies were used: five of $M$. beecheii (hereafter referred to as B1, B2, B3, B4, B5) and four of $M$. fasciata (hereafter referred to as $\mathrm{F} 1$, F2, F3, F4). The colonies were housed either in tree-trunks (B2, B3, B4, B5, F1, F2, F3) or in one-compartment hives (B1, F4) and were installed at one of two locations that were $50 \mathrm{~m}$ apart: ARBOFILIA centro de educación y investigación (B1, B5, F1, F2, F3) or at a private house (B2, B3, B4, F4). Five colonies had been in situ for at least 1 year (B1, F1, F2, F3, F4). Colony B5 was transferred from the neighbouring village of Bijagual ( $10 \mathrm{~km}$ away) to El Sur in January 1996, and B2, B3 and B4 were transferred from Santa Cruz, Guanacaste Province (about $150 \mathrm{~km}$ to NW in dry forest zone) to El Sur in midDecember 1995. The colonies consisted of an estimated $2000-3000$ individuals; B3 and B4 were exceptions in that they were estimated to contain only $1000-1500$ individuals.

To study the climatological influence on the sugar concentration of the collected nectar additional observations were performed in Pozo Azul de Abangares, Guanacaste Province, Costa Rica $\left(10^{\circ} 10^{\prime} \mathrm{N} ; 85^{\circ} 00^{\prime} \mathrm{W}\right.$; alt. $200 \mathrm{~m}$; figure I). Pozo Azul is situated in the tropical dry forest zone. Only $M$. beecheii is native to the Pozo Azul area (nb.: this Pozo Azul is different from Finca Pozo Azul regularly cited as a collection site for M. fasciata by Wille [25], which is located in rain forest environment near the Central Pacific coast, $9^{\circ} 39^{\prime} \mathrm{N} ; 8^{\circ} 18^{\prime} \mathrm{W}$ ). Colony B2 was moved from El Sur to Pozo Azul on 12 January 1996. Colony F4 was moved to Pozo Azul on 28 February after a regular sampling session in EI Sur on 27 February.

\subsection{Nectar sampling}

From 17 November 1995 (week 1) till $23 \mathrm{Fe}$ bruary 1996 (week 15) nectar samples were taken in El Sur once a week from five to ten returning foragers per colony, five times a day (07:00-08:00; 09:00-10:00; 11:00-12:00; 13:00-14:00 and 15:00-16:00). Nectar foragers carried pollen of different colours and on different parts of their bodies (but did not carry pollen loads in their corbiculae). By sampling selectively at least one forager from each visually distinguishable dusting and colour type, we obtained a wide variety of nectar samples. This may have caused a slight overestimation of the diet diversity index. Four colonies were sampled from weeks $1-15$ (B5, F1, F2, F3), B2 in weeks 11 and 13, B3 from weeks 6-11, B4 from weeks 6-13 and B5 from weeks 11-15. Temperature, relative humidity and cloudiness were recorded during each sampling session. The relative humidity $(\mathrm{RH})$ was calculated from a non-aspirated psychrometer. Cloudiness was recorded on a 5-step scale: $\mathbf{I}=$ clear sky, 2 = scattered clouds, $3=$ half cloudy, $4=$ heavy clouds, $5=$ rain .

Returning nectar foragers were caught with a suction tube. Nectar was collected from nectar foragers by means of 20 and $50 \mu \mathrm{L}$ capillary tubes (minicaps, Hirschmann) that were placed between the mandibles, while slightly pressing the bee's abdomen manually. The sugar concentration of the nectar was measured by a handheld refractometer corrected for ambient temperature (Atago 500, National Co., Japan). Refractometer values are in \% BRIX which is the weight of total dissolved solids per total weight of solution.

Nectar samples were taken from colonies F4 and B2 in Pozo Azul, on 29 February and 5 March, according to the methodology described above. 


\subsection{Pollen analysis}

To identify the nectar sources used by the bees we analysed pollen from the bodies of the nectar foragers. We did not analyse the pollen in the nectar, as has been done regularly (reviewed by [16]), because preliminary work showed that many nectar samples did not contain any pollen, whereas most bees carrying nectar had pollen grains on their bodies. Only if anthers are close to the nectar or if pollen has fallen into it, bees will imbibe pollen grains with the nectar. On other occasions pollen grains will adhere to the bees' body, but not necessarily enter the nectar. Pollen grains adhering to the body of the bee were collected by tapping the bee with a small piece of glycerine jelly mounted on a pin. The colour and the amount of the pollen were recorded as well as the part of the body from which it was collected. The glycerine jelly was melted and mounted on a microscopic slide following the addition of a drop of fuchsin. The vast majority of the slides contained only one type of pollen indicating that bees tended to collect nectar from one plant species only. Pollen slides that contained more than one type were not included in our analysis. Some bees did not carry pollen grains in adequate numbers on their bodies. The origin of the nectar harvested by such bees remains unknown, because in none of these cases did the nectar contain an identifiable amount of pollen grains. The different pollen types were coded, described, drawn and identified by making use of our reference collection (see below) and the pollen literature from Panama [20] and Yucatan [14].

\subsection{Pollen reference collection}

To facilitate identification of the plant species used as nectar sources by the bees, we prepared a pollen reference collection for the flowering plants of the area. During the 15 week observation period 3 days per week were used for the collection of flowering plants in an area of about $1 \mathrm{~km}$ around the bee colonies. Standard routes were covered, all flowering recorded and all flowering plant species (230 in total) collected, dried and kept as a reference. Vouchers were deposited at Utrecht University, the Netherlands and CINAT, Universidad Nacional, Costa Rica. A pollen slide was made of each plant collection to serve as reference for identification. Plants were identified by the authors with considerable help from José Gonzalez and Barry Hammell
(Lauraceae, Convolvulaceae) of INBIO and Luis Poveda (Compositae) of the Universidad Nacional.

\section{RESULTS}

\subsection{Sugar concentration of nectar collected by foragers}

Both species collected nectars with a wide range of sugar concentrations $(M$. beecheii: 7.1-72.4\%; M. fasciata: 6.6-65.4\%). Occasionally bees carried loads of less than $5 \%$ sugar concentration. These loads probably consist mainly of water [19] and will not be considered further. $M$. beecheii $\mathrm{col}$ lected nectar with higher sugar concentrations than $M$. fasciata overall (figure 2) and during each of the five daily sampling periods (figure 3). Sugar concentration increased from 7:00 to 11:00 and stabilised after 11:00.

A MANOVA was performed on all data (2 028 cases) to find the factors associated with sugar concentration of nectar. The results indicate that the factors species $(P<0.001)$ and colony within species $(P<0.001)$ as well as the covariants temperature $(P<0.001)$, week $(P<0.001)$ and cloudiness $(P<0.01)$ significantly explained part of the variance in sugar concentration (model explained $41.4 \%$ of the variation in sugar concentration). Using the mean sums and $t$-values as a measure of relative contribution, factors and covariants can be put in order of descending importance: bee species, week, temperature, cloudiness and colony.

\subsection{Diversity and overlap of nectar sources}

During the 15 weeks of observation the bees collected nectar from 55 different plant species, 21 of which were shared by the two species. $M$. fasciata used 47 plant species (26 exclusively) and $M$. beecheii used 29 plant species (eight exclusively). M. fas- 


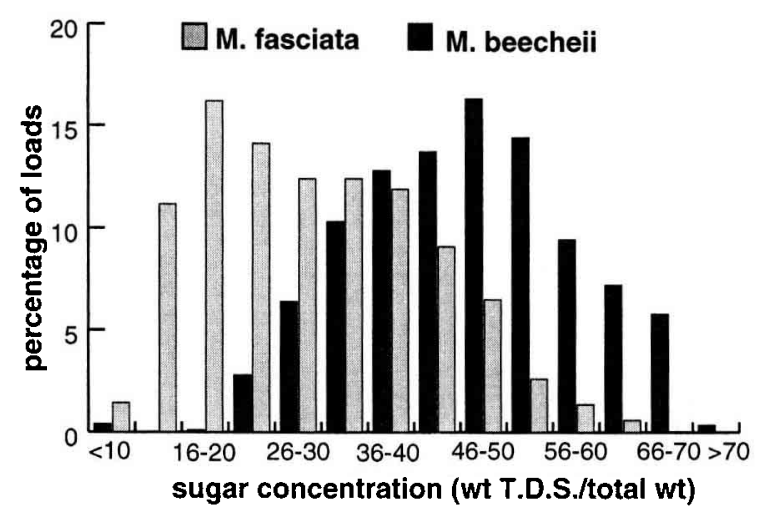

Figure 2. Sugar concentration of nectar collected by foragers of $M$. beecheii and $M$. fasciata in El Sur, Costa Rica. Dilference is highly significant $(t$-test: $t=31.25, P=0.0001 ; M$. fasciata: average $=$ 29.87 , mode $=20.5, \mathrm{SD}=12.07, \mathrm{n}=1182$, range $6.6-65.3 ;$ M. bechei $:$ average $=46.73$, ode $=53.8$, $\mathrm{SD}=11.85, \mathrm{n}=846$, range $7.1-72.4)$.

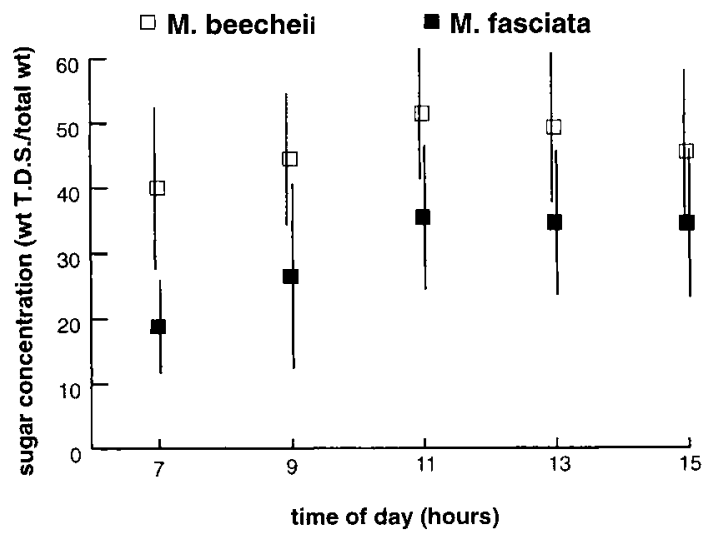

Figure 3. Variation of sugar concentration during the day of nectar collected by $M$. beecheii and M. fasciata in El Sur, Costa Rica. Given are averages \pm 1 SD.

ciata also collected nectar from a wider range of plant species per colony per week than $M$. beecheii (MWU-test: $\mathrm{Z}=5.70$, $\left.P<0.001 ; \mathrm{N}_{\text {fasciata }}=45, \mathrm{~N}_{\text {hecchcii }}=35\right)$. Colony B5 collected nectar from more plant species per week than the other colonies of $M$. beecheii (table I; MWU-test: $\mathrm{Z}=2.74$, $P<0.01 ; \mathrm{N}_{\mathrm{B} 5}=5, \mathrm{~N}_{\text {(sther B }}=30$ ).

The Shannon index of diversity, $\mathrm{H}^{\prime}$, was higher for $M$. fasciata than for $M$. beecheii (table I; MWU-test: $\mathrm{Z}=5.84, P=0.0001$; $\mathrm{N}_{\text {fasciata }}=45, \mathrm{~N}_{\text {beecheii }}=34$ ). Again colony
B5 had a higher diversity than the other $M$. beecheii colonies (MWU-test: $Z=2.62$, $P=0.01 ; \mathrm{N}_{\mathrm{B} 5}=4, \mathrm{~N}_{\text {other } \mathrm{B}}=30$ ).

Intraspecific overlap, measured as Horn's index, was higher for $M$. fasciata than for $M$. beecheii (table II). Interspecific overlap between $M$. beecheii colony 1 and the $M$. fasciata colonies was high and intermediate between the intraspecific overlap of the two species. This indicates that a considerable part of the important nectar sources was shared between the species. 
Table I. Diversity of nectar sources used by $M$. beecheii and $M$. fasciata in El Sur between November 1995 and March 1996. Number of nectar sources per week and Shannon's Diversity index (H') are given as average $\pm 1 \mathrm{SD}$.

\begin{tabular}{lccccc}
\hline & Colony & Weeks sampled & \multicolumn{2}{c}{ Plant species used } & H' average \\
\cline { 4 - 5 } & & & Total & Per weck & \\
\hline M. beecheii & B1 & 15 & 19 & $3.73 \pm 1.49$ & $0.86 \pm 0.43$ \\
29 spp. total & B3 & 5 & 6 & $2.20 \pm 1.10$ & $0.56 \pm 0.38$ \\
& B4 & 7 & 10 & $2.86 \pm 1.07$ & $0.86 \pm 0.45$ \\
& B5 & 5 & 12 & $5.60 \pm 1.67$ & $1.46 \pm 0.41$ \\
M. fasciata & F1 & 15 & 34 & $6.33 \pm 1.72$ & $1.58 \pm 0.30$ \\
47 spp. total & F2 & 15 & 26 & $6.20 \pm 1.37$ & $1.50 \pm 0.22$ \\
& F3 & 15 & 27 & $6.07 \pm 1.87$ & $1.47 \pm 0.33$ \\
\hline
\end{tabular}

Table II. Overlap in nectar sources used by $M$. fasciata and $M$. beecheii in El Sur, Costa Rica, measured as Horn's index. Given is the overall average of 15 weekly averages and minimum and maximum values of weekly overlap. Data were collected between November 1995 and March 1996.

\begin{tabular}{lllll}
\hline & \multicolumn{4}{c}{ Horn's index } \\
\cline { 2 - 5 } Intraspecific & Colony & Average & Min & Max \\
\hline M. beecheii & B1-B3 & 0.55 & 0.45 & 0.64 \\
& B1-B4 & 0.62 & 0.39 & 0.88 \\
& B1-B5 & 0.67 & 0.58 & 0.83 \\
& B3-B4 & 0.60 & 0.52 & 0.65 \\
& B4-B5 & 0.58 & 0.55 & 0.60 \\
M. fasciata & F1-F2 & 0.82 & 0.66 & 1.00 \\
& F1-F3 & 0.79 & 0.58 & 0.94 \\
Interspecific & F2-F3 & 0.70 & 0.53 & 0.83 \\
& B1-F1 & 0.73 & 0.49 & 1.00 \\
& B1-F2 & 0.75 & 0.49 & 1.00 \\
& B1-F3 & 0.75 & 0.47 & 1.00 \\
\hline
\end{tabular}

\subsection{Botanical origin of the nectar}

By means of palynological analysis half of the nectar sources could be identified at generic or species level. A nectar source was referred to as a major source if it contributed at least $30 \%$ of the samples of one colony during one observation day. All other sources are minor sources including the major sources outside their 'major' period. The presence of the major sources over the observation period is depicted in table III. Four of the 11 most important sources were Compositae (seven species in total; all herbs, vines and shrubs), two were Sapindaceae (one tree and one vine). Mimosaceae (four species total; three trees and one liana), Tiliaceae (tree), Simaroubaceae (tree) and Labi- 
atae (herb) accounted for one major source each. Additional nectar sources that are not mentioned in table III or $I V$ include Croton schiedens (Euphorbiaceae; tree), Protium sp. (Burseraceae; tree) and Cordia spinescens (Boraginaceae; liana).

\subsection{Nectar concentration harvested in relation to botanic origin}

From half the plant species they shared, M. fasciata collected significantly more diluted nectar than did $M$. beecheii. A similar trend was found for three other nectar sources $(0.1>P>0.05$; table IV). No difference was found for the remaining four shared nectar sources. $M$. fasciata collected a significantly higher sugar concentration from the plant species it shared with $M$. beecheii than from sources that it used exclusively ( $t$-test: $t=4.27 ; P<0.001$; shared sources: average $=35.3 \pm 5.6 ; \mathrm{n}=15$; exclusive sources: average $=23.6 \pm 7.6$; $\mathrm{n}=9$; table $\mathrm{IV}$ ).

\subsection{Sugar concentration of bee-collected nectar and micro-climate}

To investigate whether the interspecific differences in nectar sugar concentration were influenced by regional climatological conditions, we compared nectar foraging of $M$. beecheii and $M$. fasciata in El Sur (humid tropical forest zone) and Pozo Azul (dry tropical forest zone). Both species collected

Table III. Important nectar sources for $M$. fasciata (a) and $M$. beecheii (b) in El Sur, Costa Rica between 17 November 1995 (week 1) and 23 February 1996 (week 15). Dark shading: major source; light shading: minor source. For definition of major sources see Material and methods.

Plant species

A

Oxydaea verbesinoides

Serjania sp.

cf. Heliocarpus

Inga ruiziana

Hyptis capitata

Capania costaricensis

unidentified type 11

Bidens squarrosa

Mikania micrantha

Simarouba amara

Vernonia patens

B

Oxydaea verbesinoides

Serjania sp.

cf. Heliocarpus

unidentified type 11

Bidens squarrosa

Vernonia patens

Family

$\begin{array}{lllllllllllllll}1 & 2 & 3 & 4 & 5 & 6 & 7 & 8 & 9 & 10 & 11 & 12 & 13 & 14 & 15\end{array}$

Week

Compositac

Sapindaceale

Tiliaceae

Mimosaceae

Labiatae

Sapindaceac

Compositae

Compositae

Simaroubaceac

Compositae

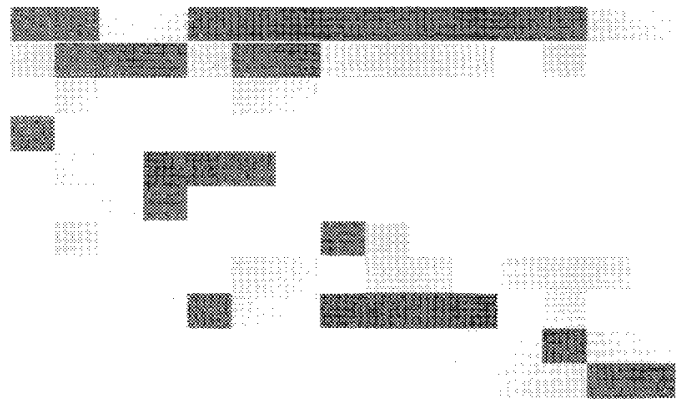

Weck

\section{Compositae \\ Sapindaceac \\ Tiliaceae \\ Composita \\ Compositae}

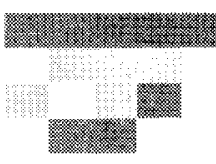

16\%

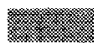


Table IV. Sugar concentration (in \% Brix) of nectar of different botanic origin obtained from returning foragers. Data were collected between November 1995 and April 1996. Significance of differences between mean values are tested using Student's t-test or Mann-Whitney test (MWU) according to sample size.

\begin{tabular}{|c|c|c|c|c|c|c|c|c|c|}
\hline \multirow[b]{2}{*}{ Plant species } & \multicolumn{3}{|c|}{ M. Beecheii } & \multicolumn{3}{|c|}{ M. fasciata } & \multicolumn{3}{|c|}{ Test result } \\
\hline & Average & SD & $\mathrm{N}$ & Average & SD & $\mathrm{N}$ & $t$-value & MWU & $P$-value \\
\hline Oxydaea verbesinoides & 44.1 & 9.5 & 182 & 40.5 & 9.4 & 182 & 3.63 & & 0.0003 \\
\hline Vernonia patens & 47.6 & 11.4 & 30 & 39.1 & 7.7 & 82 & 4.53 & & 0.0001 \\
\hline Bidens squarrosa & 42.5 & 7.3 & 27 & 42.9 & 7.1 & 19 & -0.21 & & 0.83 \\
\hline type 11 & 44.3 & 9.3 & 44 & 33.8 & 11.8 & 7 & 2.68 & & 0.01 \\
\hline cf. Heliocarpus & 52.3 & 10.8 & 24 & 42.4 & 14.3 & 4 & & -1.40 & 0.15 \\
\hline Hyptis capitata & 47.7 & 11.6 & 2 & 37.9 & 9.2 & 62 & & -1.33 & 0.18 \\
\hline Serjania sp. & 35.7 & 11.4 & 4 & 24.7 & 7.8 & 109 & & -2.05 & 0.04 \\
\hline Mikania micrantha & 39.0 & 13.0 & 4 & 34.2 & 13.6 & 79 & & -0.68 & 0.50 \\
\hline Bravaisia integerrima & 45.6 & 5.1 & 6 & 36.3 & 9.4 & 3 & & -1.81 & 0.07 \\
\hline Schlegelia parviflora & 60.0 & 14.4 & 3 & 37.1 & 3.7 & 13 & & -2.62 & 0.01 \\
\hline cf. Celtis & 49.7 & 11.7 & 2 & 27.7 & 9.7 & 4 & & -1.85 & 0.06 \\
\hline type 9 & 63.0 & 5.8 & 4 & 31.7 & 8.6 & 2 & & -1.85 & 0.06 \\
\hline type 16 & 39.2 & 9.6 & 5 & 39.8 & 11.8 & 9 & & -0.07 & 0.94 \\
\hline type 42 & 64.0 & & 1 & 27.3 & 14.1 & 10 & & & \\
\hline type 50 & 45.9 & 11.7 & 3 & 34.4 & 11.2 & 14 & & -1.26 & 0.21 \\
\hline type 60 & 45.4 & 11.1 & 6 & & & & & & \\
\hline Simarouba amara & & & & 16.7 & 8.0 & 26 & & & \\
\hline Inga Ruiziana & & & & 20.6 & 1.7 & 18 & & & \\
\hline Inga densiflora & & & & 17.0 & 1.65 & 7 & & & \\
\hline Cupania costaricensis & & & & 19.2 & 8.7 & 17 & & & \\
\hline Eugenia malaccensis & & & & 15.6 & 3.9 & 5 & & & \\
\hline type 25 & & & & 25.4 & 7.8 & 4 & & & \\
\hline type 36 & & & & 35.1 & 8.8 & 6 & & & \\
\hline type 49 & & & & 34.2 & 10.9 & 20 & & & \\
\hline type 56 & & & & 28.6 & 8.9 & 21 & & & \\
\hline
\end{tabular}

significantly richer nectar in Pozo Azul than in El Sur and $M$. beecheii collected more concentrated nectar than $M$. fasciata in $\mathrm{El}$ Sur (table $V$; 3-way ANOVA: sample site: $P<0.001$; bee species: $P<0.01$ ). The significant interaction between bees and sample sites $(P<0.05)$ reflects the fact that the nectar sugar concentration collected by the two species was quite different in El Sur (figure 3) but similar in Pozo Azul (table V). Most of the nectar at both sample sites was collected from Vernonia patens (Compositae; shrub) and Bravaisia integerrima (Acan- thaceae; tree). The sugar concentration of the nectar of these plant species showed similar variation over the sample sites and bee species (table $V$ ).

\section{DISCUSSION}

\subsection{Nectar harvesting by Melipona}

According to ecological theory, species that share a common environment need to use their environment in a slightly different 
Table V. Comparison of nectar sugar concentration collected by foragers of $M$. fasciata and $M$. beecheii at Pozo Azul (dry tropical forest) and El Sur (humid tropical forest). Average sugar concentration $\pm \mathrm{SD}$ with number of samples in parentheses for the whole data set and separate subsets of two major sources: Vernonia patens and Bravaisia integerrima.

\begin{tabular}{llcc}
\hline & Locality & M. fasciata & M. heecheii \\
\hline All data & Pozo Azul & $57.9 \pm 9.7(99)$ & $55.2 \pm 12.2(95)$ \\
& El Sur & $39.8 \pm 7.6(133)$ & $46.8 \pm 10.6(38)$ \\
Vernonia patens & Pozo Azul & $55.9 \pm 9.3(35)$ & $60.2 \pm 4.6(20)$ \\
& El Sur & $38.9 \pm 7.5(79)$ & $47.0 \pm 11.4(32)$ \\
Bravaisia integerrimal & Pozo Azul & $60.2 \pm 9.0(44)$ & $57.7 \pm 9.2 \quad(20)$ \\
& El Sur & $36.3 \pm 9.4(3)$ & $45.6 \pm 5.1 \quad(6)$ \\
\hline
\end{tabular}

way, e.g. show resource partitioning. Essential resources for bees include food sources and nest sites. We studied the partitioning of nectar resources by $M$. beecheii and $M$. fasciata. These stingless bees occur sympatrically in the Central Pacific zone of Costa Rica, but are allopatric in most of their distributions. $M$. beecheii collected richer nectars than $M$. fasciata in humid tropical Costa Rica. A similar differentiation has been reported for four Melipona species normally in overlapping disributions in Panama [19]. In Panama $M$. compressipes collected richer nectar than $M$. fasciata and in Mexico $M$. beecheii collected highly concentrated nectar [22]. This agrees with the idea that $M$. beecheii and $M$. compressipes are sister species with mutually exclusive distributions: $M$. compressipes occurs in Panama but not in Costa Rica, whereas $M$. beecheii occurs in Costa Rica and not in Panama [5]. The results suggest that $M$. fasciata and $M$. beecheii are consistent in their respective low- and high-sugar specialisation in different parts of their distribution.

\subsection{Sugar concentration of nectar harvested by Melipona}

Many different factors may influence the sugar concentration of nectar harvested by Melipona. With the present results we can disprove the influence of some factors and suggest which are the main factors for the interspecific differences.

The first set of factors are those related to the botanical origin of the nectar and flower choice in the field. It is clear that preference for different plant species or different flower types has at the most only limited impact. The two species collected nectar from plant species in the same families and with similar morphology (mostly open and some tubular flowers) and shared many of their major nectar sources (tables $I I$ and $I V$ ). The fact that $M$. beecheii collected more concentrated nectar from the same plant species than $M$. fasciata indicated that the two species use different foraging strategies that leads them to visit different patches (or subpatches) within the same habitat.

Climatological factors, e.g. temperature and humidity, are known to influence the sugar concentration of floral nectar. At the dry climate site (Pozo Azul) both species collected richer nectar than at the humid climate site owing to the fact that both major sources ( $V$. patens and B. integerrima) produced richer nectar in Pozo Azul than in El Sur. The two Melipona species collected nectars of similar richness in the dry climate. This clearly indicates that local climate highly influenced the sugar concentration presented by the plants and harvested 
by the bees. In dry forest habitat almost no humid shady places are present in the dry season; however, in the rain forest habitat of El Sur both sunlit and shaded patches are abundant in the dry season, especially before noon. Therefore, it is hypothesised that in the dry season the bees partition nectar sources based on patch climate in the wet forest habitat, but not in the dry forest habitat.

We are aware that differences in sugar concentration of bee-collected nectar can be (partly) due to other factors, such as bee morphology (e.g. tongue characteristics, body size and colour), specific needs of social bees (e.g. colony thermo-regulation and humidity regulation) or interspecific competition. The influence of these "beerelated' factors on partitioning of nectar resources by the two species of Melipona are dealt with in another paper [4].

\subsection{Behavioural regulation of partitioning of nectar resources}

This study does not address the question in what aspect of their foraging strategies $M$. beecheii and $M$. fasciata differ. However, it was shown that even at the same time of day the differences are considerable, so that we can rule out temporal differences in foraging activity. Moreover, the habitat was not different further away from the hives than close by, so that even if the species foraged at different distances from the colony it would not have led to differences in harvested nectar (additional observations demonstrated that neither of the species changed the nectar sugar concentration between collecting and returning home - unpubl. data). Interspecific differences in communication system could not have lead to such results, because we standardised the number of samples per colony per hour and it resulted that different nectar quality was collected from the same plant species.
Among the behavioural traits that are most likely to explain the observed differences in nectar quality are competitive ability of the species [10], innate preference for certain sugar concentration or type, optimal sugar intake rates (but see $[19,22]$ ) and tolerance to direct insolation [26]. Differences in sunlight regime contribute to the distribution of bees over flower patches ([26]; Biesmeijer, unpubl. data). In El Sur lightcoloured stingless bees seem to be more abundant on the sunlit patches than in the shade, whereas the dark-coloured bees are more abundant in the shade. Consequently, body colour may be an additional factor in the partitioning of nectar resources between the light-coloured $M$. beecheii and the darkcoloured $M$. fasciata, but other morphological and physiological factors as well as interspecific competition cannot be excluded. This study clearly shows that the sugar content of bee-collected nectar is based partly on food plant choice and local climate.

\subsection{Why is $M$. fasciata absent from the dry forest in NW Costa Rica?}

The foraging activity of $M$. fasciata colony F4 was very high during its 3 week stay in Pozo Azul, indicating that lack of food is not the main reason for its natural absence in the tropical dry forest zone in Costa Rica. In the longer term, regulation of the colony climate may be a problem for $M$. fasciata in the tropical dry forest, because it did not collect water during the observations to cool down the colony ( 0 of 99 loads contained less than $5 \%$ sugar in Pozo Azul) but, in general, harvests watery nectar ( figure 1). In the tropical dry forest no watery nectar was available during the observations in the middle of the dry season. $M$. fasciata, however, did not switch to water collecting which may in the long run lead to overheating of the colony and damage to brood or nest structures. $M$. beecheii does collect water during dry hot weather ( 14 of 
108 loads contained less than $5 \%$ sugar in Pozo Azul) and is capable of regulating its colony climate under such circumstances. The behavioural difference may be the key to the largely allopatric distribution of $M$. beecheii and M. fasciata in Costa Rica and most of its range.

\section{ACKNOWLEDGEMENTS}

Miguel Soto and the other members of ARBOFILIA allowed us to use their bees, arranged our stay in El Sur and were very helpful in many ways. Our colleagues from CINAT and PRAM let us use their facilities and assisted on many occasions. Fernando Ramirez helped to obtain some bee colonies. The people of El Sur and Pozo Azul are thanked for their friendship and help. Plants were identified with the help of Luis Poveda (Universidad Nacional, Heredia) and José Gonzalez and Barry Hammell (INBIO, Santo Domingo). Hayo Velthuis, Dick Koedam, Judith Slaa and two anonymous referees made valuable suggestions that improved the manuscript and Sheila McNab made linguistic improvements. This study was financed by the Netherlands foundation for research in the tropics (WOTRO), the Lucy Burgers Foundation, Uyttenboogaart-Eliasen Foundation and STIR (Utrecht University).

Résumé - Récolte de nectar par les abeilles sans dard du Costa Rica : influence de l'origine botanique et du climat sur la concentration en sucres du nectar récolté par Melipona. La récolte de nectar par deux mélipones indigènes, Melipona beecheii et Melipona fasciata (Apidae, Meliponinae), a été étudiée au Costa Rica. Les deux espèces ont une aire de répartition qui se recouvre dans une petite partie du Costa Rica (figure I). M. beecheii se rencontre principalement dans la forêt sèche du NW du pays, tandis que $M$. fasciata est présente dans tous les habitats de la forêt pluviale. Les mesures de la concentration en sucres du nectar récolté par les butineuses montrent que dans le milieu de la forêt tropicale humide $M$. beecheii récolte uniformément un nectar plus riche que $M$. fasciata (figure 2). La concentration en sucres augmente durant la matinée et se stabilise après $11 \mathrm{~h}$ (figure 3 ).

En comparant le pollen présent sur le corps des butineuses et le pollen des fleurs présentes dans la région, on s'aperçoit que les sources de nectar utilisées par les deux espèces se recouvrent considérablement (tableau II). Le tableau III donne les principales sources de nectar durant la période d'observation. $M$. beecheii récolte du nectar plus riche en sucres que $M$. fasciata, y compris lorsqu'elles butinent toutes deux les mêmes espèces. En moyenne $M$. fasciata récolte des nectars à concentration en sucres plus faible sur les espèces qu'elle utilise seule que sur les espèces qu'elle partage avec $M$. beecheii (tableau IV). L'origine botanique du nectar explique donc en partie, mais pas en totalité, la différence dans la concentration en sucres des nectars récoltés par chacune des deux espèces.

La différence observée sur le site de la région tropicale humide ne se retrouve pas sur le site à climat tropical sec, où $M$. beecheii est présente naturellement et où une colonie de $M$. fasciata a été introduite. Dans l'habitat sec, les deux espèces récoltent du nectar plus concentré que dans la région humide, ceci même pour des plantes de la même espèce (tableau $\mathrm{V}$ ). Les résultats suggèrent que le comportement de butinage des abeilles est à la base du partage des ressources dans les forêts humides. (C) Inra/ DIB/AGIB/Elsevier, Paris

Melipona / récolte nectar / teneur en sucres / analyse pollinique / plante nectarifère / partage ressources / Costa Rica

\section{Zusammenfassung - Nektarsammeln der stachellosen Bienen in Costa Rica: bota- nische und klimatische Einflüsse auf die Zuckerkonzentration im von Meliponen eingetragenen Nektar. Das Sammeln von Nektar durch zwei heimische stachellose Bienenarten, Melipona beecheii und Meli-}


pona fasciata, wurde in Costa Rica untersucht. Das Vorkommen beider Arten überlappt dort in einer schmalen Zone $(A b b . I)$. $M$. beecheii lebt hauptsächlich im Trockenwald in Nordwest Costa Rica, während sich der Lebensraum von $M$. fasciata über den ganzen Regenwald erstreckt. Messungen der Zuckerkonzentration des von Sammlerinnen eingetragenen Nektars zeigte, dass $M$. beecheii im tropischen Regenwaldes bei hoher Luftfeuchte immer konzentrierteren Nektar sammelte als $M$. fasciata (Abb. 2). Die Zuckerkonzentration zeigte jeden Morgen einen Anstieg, stabilisierte sich jedoch nach 11:00 Uhr (Abb. 3).

Ein Vergleich der Pollen am Körper der Nektarsammlerinnen mit Pollen von Pflanzen zeigte, daß sich die Nektarquellen der beiden Arten beträchtlich überlappten (Tabelle II). M. beecheii sammelte Nektar mit einem höheren Zuckergehalt wie $M$. fasciata, selbst wenn er von der gleichen Pflanze stammte. Im Durchschnitt sammelte $M$. fasciata geringere Zuckerkonzentrationen von Pflanzenarten, die ausschliesslich von ihr besammelt wurde, als von solchen, die auch von $M$. beecheii beflogen wurde (Tabelle $I V$ ). Demnach lassen sich die Unterschiede in den Zuckerkonzentrationen zwischen den beiden Arten nur zum Teil durch die botanische Herkunft des Nektars erklären. Obwohl sich ein Unterschied in der Zuckerkonzentration des eingebrachten Nektars in feuchten, tropischen Gebieten ergab, war dieser Unterschied im trockenen, tropischen Bereich nicht nachzuweisen. Für den Versuch wurden Völker von $M$. fasciata in den trockenen Bereich angesiedelt, während $M$. beecheii dort natürlicherweise vorkommt. Im trockenen Lebensraum sammelten beide Arten von denselben Pflanzenarten konzentrierteren Nektar als in dem feuchten Gebiet (Tabelle V). Es wird angenommen, dass das Sammelverhalten der Bienen die Grundlage für die Aufteilung der Nahrungsressourcen in feuchten Wäldern bildet. () Inra/DIB/AGIB/Elsevier, Paris

\section{Nektareintrag / Zuckerkonzentration / Melipona / Pollenanalyse / Costa Rica}

\section{REFERENCES}

11 Ayala. R., Revisión de las abejas sin aguijón de Mexico (Hymenoptera: Apidae: Meliponinae), MSc thesis, UNAM, Mexico, 1992.

12] Baker H.G., Baker I., Studies of nectar-constitution and pollinator-plant coevolution, in: Gilbert G.E., Raven P.H. (Eds.), Animal and Plant Coevolution, Austin, Texas, 1975, pp. 100-138.

[3] Baker H.G., Baker I., Floral nectar sugar constituents in relation to pollinator type, in: Jones C.E., Little R.J. (Eds.), Handbook of Experimental Pollination Biology, van Nostrand Reinhold, New York, 1983, 117-141.

[4] Biesmeijer J.C., Richter J.A.P., Smeets M.J.A.P., Sommeijer M.J., Niche differentiation in nectar-collecting stingless bees: the influence of morphology, floral choice, and interspecific competition, Ecol. Entomol. (in press).

15] Camargo J.M.F. de, Moure J.S., Roubik D.W. Melipona yucatanica new species (Hymenoptera: Apidae: Meliponinae); stingless bee dispersal across the Caribbean arc and post-Eocene vicariance, Pan-Pacific Entomol. 64 (1988) 147-158.

[6] Faegri K., van der Pijl L., The Principles of Pollination Ecology, Pergamon Press, Oxford, 1979.

17] Hanson P.E., Gauld I.D. (Eds.), The Hymenoptera of Costa Rica, Oxford Univ. Press, Oxford, 1995.

[8| Heithaus E.R., Flower visitation records and resource overlap of bees and wasps in northwest Costa Rica, Brenesia 16 (1979) 9-52.

19] Heithaus E.R., Community structure of neotropical flower visiting bees and wasps: diversity and phenology, Ecology 60 (1979) 190-202.

[10| Johnson L.K., Hubbell S.P., Aggression and competition among stingless bees: field studies, Ecology 55 (1974) 120-127.

[1 I] Kleinert-Giovannini A., Imperatriz-Fonseca V.L., Aspects of the trophic niche of Melipona marginata marginata Lepeletier (Apidae, Meliponinae), Apidologie 18 (1987) 69-100

[12] Martínez-Hernández E., Cuadricllo-Aguilar J.I., Téllez-Valdez. O., Ramírez-Arriaga E., SosaNájera M.S., Melchor-Sánchez J.E.M., MedinaCamacho M., Lozano-García M.d.S., Atlas de las plantas y el polen utilizados por las cinco especies principales de abejas productoras de miel en la región del Tacana, Chiapas, Mexico, UNAM, Mexico DF, 1993.

[13] Opler P.A., Nectar production in a tropical ecosystem, in: Bentley B., Elias T. (Eds.) The Biology of Nectaries, Columbia Univ. Press, New York, 1983.

114] Palacios-Chávez R., Ludlow-Wiechers B., Villanueva R., Flora palinologica de la reserva de la biosfera de sian ka'an Quintana Roo, Mexico, Centro de investigaciones de Quintana Roo (CIORO), 1991. 
[15] Ramalho M., Kleinert-Giovannini A., Imperatriz-Fonseca V.L., Utilization of floral resources by species of Melipona (Apidae, Meliponinae): floral preferences, Apidologie 20 (1989) 185-195.

[16] Ramaiho M., Kleinert-Giovannini A., Imperatriz-Fonseca V.L., Important bee plants for stingless bees (Melipona and Trigonini) and Africanized honeybees (Apis mellifera) in neotropical habitats: a review, Apidologie 21 (1990) 469-488.

[17] Roubik D.W., Ecology and Natural History of Tropical Bees, Cambridge Univ. Press, Cambridge, 1989.

[18] Roubik D.W., Stingless bees (Apidae: Meliponinae): a guide to panamanian and mesoamerican species and their nests, in: Quintero D., Aiello A. (Eds.), Insects of Panama and Mesoamerica, Oxford Univ. Press, Oxford, 1992. pp. 495-524.

[19] Roubik D.W., Buchmann S.L., Nectar selection by Melipona and Apis mellifera (Hymenoptera: Apidae) and the ecology of nectar intake by bee colonies in a tropical forest, Oecologia 61 (1984) $1-10$.

[20] Roubik D.W., Moreno J.E., Pollen and spores of Barro Colorado Island, Missouri Bot. Garden, 1991.
[21] Roubik D.W., Moreno J.E., Vergara C. Wittmann D., Sporadic food competition with the African Honeybee: projected impact on neotropical stingless bees, J. Trop. Ecol. 2 (1986) $97-111$

[22] Roubik D.W., Yanega D., Aluja S. M., Buchmann S.L., Inouye D.W., On optimal nectar foraging by some tropical bees (Hymenoptera: Apidae), Apidologie 26 (1995) 197-211.

[23] Schwarz H.F., The genus Melipona, Bull. Am. Mus. Nat. Hist. 63 (1931) 231-460.

[24] Sommeijer M.J., Rooy G.A. de, Punt W., Bruijn L.L.M. de, A comparative study of foraging behaviour and pollen resources of various stingless bees (Hym., Meliponinae) and honey bees (Hym., Apinae) in Trinidad, West-Indies, Apidologie 14 (1983) 205-224.

[25] Wille A., Las abejas jicotes del genero Melipona (Apidae, Meliponinae) de Costa Rica, Rev. Biol. Trop. 24 (1976) 123-147.

[26] Willmer P.G., Corbet S.A., Temporal and microclimatic partitioning of the floral resources of Justicia aurea amongst a concourse of pollen vectors and nectar robbers, Oecologia 51 (1981) $67-78$. 